Please cite as a Chapter in Comparative Criminal Procedure, Darryl Brown, Jenia Turner, and Bettina Weisse, eds., Oxford U. Press (forthcoming 2018)

\title{
International Corporate Prosecutions
}

\section{Brandon Garrett*}

\section{Introduction}

One of the most remarkable stories in criminal law is the recent rise of corporate prosecutions across the world. In the past, even in countries that permitted corporations to be prosecuted for crimes, such prosecutions were not a common practice and any fines were minimal. In the past fifteen years, though, in the United States, many of the largest corporate prosecutions in the world have been brought, often involving international crimes by multinational companies. Billion dollar corporate penalties are now a regular occurrence. Multinational prosecutions have also involved cooperation by prosecutors across countries and parallel prosecutions of the same corporation for crimes committed in different countries.

Over the past decade and a half, federal prosecutors in the U.S. have adopted an approach in which settlement negotiations with companies are resolved, sometimes through a plea agreement, but in the largest cases, with agreements entered largely out of court and without judicial oversight. These agreements, called deferred and non-prosecution, have added new flexibility but also some additional uncertainty to the practice of corporate prosecutions. This U.S. approach has impacted countries that have sought to emulate the U.S. approach or adopted approaches seeking to improve upon it. In this Chapter, I discuss how this new U.S. approach has altered the international corporate prosecution landscape.

First, I discuss how traditionally, in most countries, corporate or entity-based criminal liability is limited and unavailable for many types of crimes. However, in recent years, this has changed. More countries have expanded corporate criminal liability, including in response to treaties like the OECD and the Lisbon Treaty which encouraged E.U. members to adopt criminal sanctions to legal persons. An additional driver of these changes has been a response to enforcement approaches in the U.S. Second, I discuss how when many countries do adopt

\footnotetext{
* White Burkett Miller Professor of Law and Public Affairs and Justice Thurgood Marshall Distinguished Professor of Law, University of Virginia School of Law.
} 
criminal liability for entities, they do so for specific crimes. Indeed, although in the U.S. there is a general and broad federal respondeat superior standard, corporate criminal enforcement patterns vary quite a bit depending on the area. Settlements in foreign bribery cases look very different than settlements in pharmaceutical cases, and in some areas, like in Antitrust, the entire enforcement approach is distinct.

The general approach relying on more informal settlements with corporations has also spread, making corporate prosecutors possible, perhaps, in countries that had been reluctant to bring criminal cases against corporations. In some criminal practice areas, such as foreign bribery prosecutions, almost all cases brought in the U.S. and around the world have been resolved through settlements. Both enforcers and corporations may seek to settle cases, since criminal convictions may implicate debarment or suspension of companies from government contracts or programs. In turn, more countries have considered adopting a U.S.-style corporate settlement program. In foreign bribery cases, that is already the case, not just in the U.S., but in other countries, including Canada, Costa Rica, Denmark, Germany, Greece, Italy, Japan, the Netherlands, Nigeria, Norway, and Switzerland, in which corporate bribery cases have been resolved through settlements. ${ }^{1}$ The U.K. has introduced a deferred prosecution agreement program modelled on that in the U.S. Law commissions and legislators in Australia, ${ }^{2}$ Canada, ${ }^{3}$ and Ireland ${ }^{4}$ have considered adopting such approaches. In France, new bribery legislation rejected such an approach. The OECD Working Group on Bribery has raised detailed questions concerning out of court settlements.

If corporate cases are to be settled, due to their informality, flexibility, or reduced collateral consequences, a series of practical questions then arise. What should the substance of the terms of corporate prosecution agreements contain? How should fines be assessed? How should compliance be measured and evaluated? How should compliance or governance be improved through the use of such agreements? To what degree should collateral consequences be considered? To what degree should companies be rewarded for self-reporting or for cooperation

\footnotetext{
${ }^{1}$ World Bank/Star, Left Out of The Bargain: Settlements in Foreign Bribery Cases and Implications for Asset Recovery 17-32 (2014), at http://star.worldbank.org/star/sites/star/files/9781464800863.pdf.

${ }^{2}$ Parliament of Australia, An Inquiry Into the Measures Concerning the Activities of Australian Corporations, Entities, Organisations, Individuals, Government and Related Parties with Respect to Foreign Bribery, at ${ }^{3}$ Institute for Research on Public Policy, Finding the Right Balance: Policies to Combat White-Collar Crime in Canada and Maintain Integrity of Public Procurement (March 2016).

${ }^{4}$ Law Reform Commission, Issues Paper on Regulatory Enforcement and Corporate Offences, Jan. 27, 2016, at http://www.lawreform.ie/news/issues-paper-on-regulatory-enforcement-and-corporate-offences-.607.html.
} 
in investigation of individual employees or officers? How long should the agreements be? What should the consequences be for a breach, and who should decide whether there is a breach? Who should supervise the implementation of a corporate prosecution agreement? To what degree can victims be involved and compensated? What credit should be given for enforcement and penalties in other jurisdictions? Each of these questions raises important and challenging issues. Each has been the subject of real disagreement in the United States experience with corporate prosecutions in recent years. To discuss corporate criminal liability, and not whether the corporation should cooperate in the prosecution of individual officers and employees, and to what degree those individual prosecutions should be prioritized, leaves out the central goal of criminal law: to hold wrongdoers accountable. The differences among enforcers regarding how to best answer those questions help to illustrate the challenges of holding corporations adequately accountable.

This Chapter begins by discussing: (1) varying standards for corporate criminal liability; then (2) underlying corporate crimes and how standards and enforcement approaches may vary depending on the type of crime; (3) settlement approaches towards corporate criminal cases; (4) criticisms of corporate crime settlement approaches; and (5) international approaches and cooperation in corporate crime cases. There are no definitive answers to the question whether to adopt one approach or another towards corporate criminal liability. Corporate crimes can be incredibly costly and serious, but hopefully the experimentation with enforcement approaches will continue to produce increased enforcement and stronger deterrents against corporate crime across the globe.

\section{Standards for Corporate Criminal Liability}

Few foreign countries have anything like the broad standard for corporate criminal liability that the United States has long had in federal courts in any specific area of criminal liability, much less as a general standard for corporate criminal liability. Corporate criminal liability has long existed in the United Kingdom, the United States, and the Netherlands. Other common law countries such as Australia, Canada, and New Zealand also have some form of corporate criminal liability, but in most the concept remains quite narrow. However, civil law 
countries in Europe, Latin America, and elsewhere long had no corporate criminal liability except in limited areas, such as in antitrust or environmental crimes. ${ }^{9}$

Many countries viewed it conceptually problematic to hold an artificial entity liable for criminal acts of agents. For example, Germany has long lacked corporate criminal liability; instead, it may apply enhanced civil administrative penalties if a corporation violates a criminal provision. ${ }^{10}$ In the past two decades, more European countries have enacted corporate criminal statutes, partially in response to principles from the European Union and Council of Europe that member states adopt some form of corporate criminal accountability. Another Chapter in this Volume discusses those changes. ${ }^{11}$ France was the first European country to introduce corporate criminal liability, in 1994 (expanded to all offenses in 2005), ${ }^{12}$ with Brazil introducing it in 1998, Belgium in $1999,{ }^{13}$ Italy in $2001,{ }^{14}$ and Spain in $2010 .{ }^{15}$ Countries in Asia including China, India, Japan, and Korea, the Middle East, including Israel, Qatar, and the United Arab Emirates, and in Africa including South Africa, have also adopted corporate criminal liability.

The United States adopts the broadest standard for corporate criminal liability. State prosecutors targeted corporations for crimes, particularly the common law crime of nuisance, in the nineteenth century. ${ }^{16}$ By the twentieth century, federal prosecutors began to pursue charges more often, particularly after the Supreme Court affirmed a respondeat superior standard for corporate criminal liability in $1909 .{ }^{17}$ The respondeat superior standard used in federal courts in the United States, permits a corporation to be prosecuted for the actions of an agent within the scope of employment. The crime committed by the employee must have been for the benefit of the corporation or organization, but they may have also benefited or even primarily benefited the employee. It does not have to be a high-level employee or officer. The company may have had

\footnotetext{
${ }^{9}$ For an excellent and detailed overview, see Mark Pieth and Radha Ivory, Emergence and Convergence: Corporate Criminal Liability Principles in Overview, in Corporate Criminal Liability (Peith and Ivory, eds., Springer 2011).

${ }^{10}$ Article 30 of the Ordnungswidrigkeitsgesetz (OWiG), or the Administrative Offenses Act; for a description of the use of this provision in bribery cases in Germany, see OECD, Phase 3 Report on Implementing the OECD AntiBribery Convention in Germany (2011), 33, http://www.oecd.org/germany/Germanyphase3reportEN.pdf.

${ }^{11}$ See [Juliette Tricot, chapter 24].

${ }^{12} 31$ December 2005 (Law No 2004-204 of 9 March 2004).

${ }^{13}$ Law of 4 May 1999.

${ }^{14}$ Decreto Legistativo no. 231 of 2001 ("Law 231").

15 Clifford Chance, Corporate Liability in Europe (January 2012), at https://www.cliffordchance.com/content/dam/cliffordchance/PDFs/Corporate_Liability_in_Europe.pdf.

${ }^{16}$ Edward B. Diskant, Comparative Criminal Liability: Exploring the Uniquely American Doctrine Through Comparative Criminal Procedure, 118 Yale L. J. 126, 134-35 (2008).

${ }^{17}$ N.Y. Cent. \& Hudson River R.R. v. United States, 212 U.S. 481, 491-95 (1909) (approving corporate criminal liability under a respondeat superior standard).
} 
policies counseling against such conduct or instructed its employees not do engage in such conduct, but the company is nevertheless strictly liable. That federal standard in the U.S. is the broadest in use in the world. However, that standard has been moderated in practice by charging guidelines used by the U.S. Department of Justice (DOJ) as well as by sentencing guidelines for organizations, which I will discuss further in sections to follow. ${ }^{18}$

Most countries that adopt some version of corporate criminal liability have begun to do so cautiously. Countries adopt corporate criminal liability either for certain specific crimes, or they limit corporate criminal liability under more general laws to conduct involving specific crimes or "leading persons" such as high-level officers. ${ }^{19}$ Indeed, within the United States, many states do not use the federal respondeat superior standard, and instead they use the Model Penal Code requirement that conduct by an employee be permitted or tolerated by management. ${ }^{20}$ In France, for example, the corporation may be convicted only if employees acted through express power of attorney or delegation of power to employees; however, more recent cases have expanded the concept of delegation to include negligent supervision or compliance. ${ }^{21}$

In the United Kingdom, an "identification approach" had long been followed. Corporations have long been held criminally liable in the U.K. ${ }^{22}$ A corporation is liable if senior officers acted as the "directing mind" in committing crimes. Although its courts had rejected respondeat superior liability, ${ }^{23}$ the U.K. has adopted a respondeat superior approach in more recent legislation. The Corporate Manslaughter and Homicide Act of 2007 adopted respondeat superior for entities when gross negligence causes a person's death. ${ }^{24}$ The U.K. Bribery Act of 2010 similarly permits strict liability for organizations that fail to prevent bribery. ${ }^{25}$ Thus, the standards for corporate criminal liability have broadened and moved more towards a strict standard along the lines of the federal standard in the U.S.

\footnotetext{
${ }^{18}$ U.S. Attorneys' Manual, § 9-28.000, Principles of Federal Prosecution Of Business Organizations (revised in November, 2015), at http://www.justice.gov/usam/usam-9-28000-principles-federal- prosecution-businessorganizations.

${ }^{19}$ Sara Sun Beale and Adam G. Safwat, What Developments in Western Europe Tell Us about American Critiques of Corporate Criminal Liability, 8 Buffalo Crim. L. Rev. 110 (2004); Luca Enriques, Bad Apples, Bad Oranges: A Comment from Old Europe on Post-Enron Corporate Governance Reforms, 38 Wake Forest L. Rev. 911 (2003).

${ }^{20} \mathrm{MPC} \S 2.07$.

${ }^{21}$ Clifford Chance, supra, at 10.

${ }^{22}$ Regina v. Birmingham \& Gloucester Railway, 114 Eng. Rep. 492 (Q.B. 1842).

${ }^{23}$ See, e.g., Tesco Supermarkets v. Natrass, [1972] A.C. 153 (H.L.) (appeal taken from Q.B.).

${ }^{24}$ Corporate Manslaughter and Homicide Act, 2007, c. 19, § 1 (Eng.).

${ }^{25}$ The Bribery Act 2010 (c.23).
} 
In Australia, most states follow the identification approach from the U.K. However, as in the U.K., legislation has broadened corporate criminal liability in recent years. The federal Criminal Code Act of 1995 adopts respondeat superior liability. ${ }^{26}$ Further, if the crime requires only negligence, then the corporation can be held liable "as a whole" by "aggregating the conduct" of employees, agents or officers. ${ }^{27}$ Corporate culture can be considered when deciding whether a corporation should be held accountable for an offense requiring a showing of knowledge, recklessness, or intent. The corporation may also be liable for negligence based on corporate culture, including policies, practices, compliance, or training, or evidence the company tolerated or supported commission of such a crime. ${ }^{28}$ For crimes with higher levels of intent required, a high-level agent must carry out or authorize the crime, or a company can be liable based on a corporate culture that "directed, encouraged, tolerated, or led to non-compliance." 29

Canadian courts follow the same identification standard as in the U.K., although they may look lower down in the corporation to identify the relevant "directing mind." A new law in Canada makes it a crime for a company to engage in gross negligence as well as negligent supervision that leads to harm to workers or the public. For crimes that require a higher mental state, prosecutors must show that higher-level officers had that intent. ${ }^{30}$

A useful overview of corporate criminal liability standards in a range of countries can be found in a Fall 2016 OECD Stocktaking Report, which surveyed the corporate criminal liability standards of its member countries. ${ }^{31}$ The OECD found that at least 38 countries $(93 \%$ of OECD members) can hold legal persons liable "when a person with the highest level of managerial authority commits the offence." At least 31 countries (76\%) also hold an organization liable if a person with managerial authority directs or authorizes the criminal acts. At least 29 countries hold companies liable if an officer or other manager fails to prevent the offence "through a failure to supervise ... or ... a failure to implement adequate controls." Still other countries adopt corporate criminal liability but permit, as a defense, a corporation to avoid criminal liability if it shows that it exercised due diligence. For example, Belgium, Italy, Poland, and Spain have such

\footnotetext{
${ }^{26}$ Austl. Criminal Code Act, 1995, § 12.2.

${ }^{27} I d . \S 12.4(2)$.

${ }^{28} I d . \$ 12(2)$.

${ }^{29} I d . \S 12.3(2)(\mathrm{c})-(\mathrm{d})$.

${ }^{30}$ Canada Crim. Code, R.S.C., ch. C-46, § 217.1 (2009).

31 OECD, The Liability of Legal Persons for Foreign Bribery: A Stocktaking Report (2016), http://www.oecd.org/corruption/anti-bribery/Liability-Legal-Persons-Foreign-Bribery-Stocktaking.pdf.
} 
affirmative defenses. ${ }^{32}$ There has been discussion among academics about whether such a defense would be useful in other countries, including the U.S. One concern is whether a company at which crimes were committed could easily show that its compliance was adequate. A separate practical concern is that corporations tend not to want to litigate corporate crimes, and compliance may already informally affect settlement negotiations.

\section{Underlying Corporate Crimes}

In the U.S., a variety of crimes are commonly charged as against corporations, including antitrust, environmental crimes, foreign bribery, fraud, money laundering offenses, securities fraud, and others. Some of these crimes, like the federal crimes of wire fraud and mail fraud, are incredibly broad. Different approaches to various crimes characterize how prosecutors respond to corporate criminal liability.

One of the most distinct and successful approaches is the U.S. Department of Justice's Antitrust Division's Leniency Program. That approach strongly incentivizes firms to be the first to report cartel behavior, relying on the inherent instability of price fixing cartels among competitors. ${ }^{33}$ Many countries have adopted similar approaches towards price fixing cartel enforcement, and parallel civil litigation is now common. There has been a "convergence in leniency programs," with dozens of countries adopting programs modelled on the U.S. Antitrust Division approach. ${ }^{34}$ In turn, this has made it "more attractive for companies to simultaneously seek and obtain amnesty in the United States, Europe, Canada and other jurisdictions." ${ }^{35}$ Converging approaches, cooperation in investigations, and a priority on antitrust enforcement in countries like the U.S., has encouraged more enforcement around the world.

Other groups of federal prosecutors in the U.S. have adopted their own distinct approaches. The U.S. Department of Justice's Tax Division adopted a programmatic amnesty program for Swiss Banks facilitating tax evasion in the U.S., with a structured set of settlement

\footnotetext{
${ }^{32}$ Clifford Change, supra, at 2.

${ }^{33}$ Antitrust Division, Leniency Program, at http://www.justice.gov/atr/leniency-program.

${ }^{34}$ Gary R. Spratling \& D. Jarrett Arp, The International Leniency Revolution 8-9 (2003), at http:// www.gibsondunn.com/publications/pages/TheInternationalLeniencyRevolution.aspx.

35 J. Anthony Chavez, More Aggressive Action to Curb International Cartels, 1739 Practising L. Inst. Corp. 807 , 813-16, 839 (2009).
} 
options designed to incentivize self- reporting, cooperation, and disclosure of names of taxpayers.

U.S. environmental crime enforcement is also distinct. The Environment and Natural Resources Division at the DOJ does not normally use deferred and non-prosecution agreements. Civil enforcers bring tens of thousands of civil actions each year, but they refer few cases to criminal prosecutors. When criminal cases are brought, plea agreements with criminal convictions are the norm. In the area of vessel pollution, the International Convention for the Prevention of Pollution from Ships has played an important role, leading to the enactment of the Act to Prevent Pollution from Ships (APPS) and to increased U.S. enforcement in recent years. ${ }^{36}$ The cases are often brought to the attention of the Coast Guard due to a whistleblower program rewarding seamen who report illegal oily discharges to them; the reward may consist in as much as half of the criminal fine, and the fines in these cases are sometimes in the millions of dollars. ${ }^{37}$

The Fraud Section has adopted a detailed pilot program for Foreign Corrupt Practices Act (FCPA) cases involving foreign bribery, with very detailed rules for what degree of leniency corporations may receive depending on their self-reporting and cooperation, as well as the conduct. The Fraud Section notes that the U.S. "is not going at this alone," and has been adopting "an international approach" by working collaboratively with law enforcement "around the globe." Recent cases depending on international cooperation included FCPA prosecutions of Acher Daniels Midland, Alcoa, Alstom, Dallas Airmotive, Hewlett-Packard, IAP, Marubeni, Parker Drilling, PetroTiger, Total, and Vimpelcome. ${ }^{38}$

As described, in some of these specific areas, countries that otherwise do not have corporate criminal liability have adopted corporate criminal liability statutes. In the area of foreign bribery, more countries now have specific legislation for corporate criminal liability. While the OECD does not require that member states adopt corporate criminal liability if their legal system does not currently have it, the OECD Anti-Bribery Convention and the U.N. Convention Against Corruption have encouraged enactment of anti-corruption legislation

\footnotetext{
${ }^{36}$ The Act to Prevent Pollution from Ships, 33 U.S.C. $\S \$ 1901-15$ (2006); see International Convention for the Prevention of Pollution from Ships, Nov. 2, 1973, 12 I.L.M. 1319, amended by Protocol, Feb. 17, 1978,17 I.L.M. 546 (also known as MARPOL); see also H.R. Rep. No. 96-1224, at 1-2 (1980).

3733 U.S.C. $\$ 51908$ (b) (2006) ("An amount equal to not more than $1 / 2$ of such penalties may be paid by the Secretary, or the Administrator as provided for in this chapter, to the person giving information leading to the assessment of such penalties.").

${ }^{38}$ U.S. Department of Justice, The Fraud Section's Foreign Corrupt Practices Act Enforcement Plan and Guidance, 1-2 (April 5, 2016), at https:/www.justice.gov/criminal-fraud/file/838416/download.
} 
generally. ${ }^{39}$ As described, France adopted new corporate criminal provisions as part of its comprehensive anti-corruption legislation. The Ukraine also recently adopted corporate criminal liability as part of anti-corruption legislation. ${ }^{40}$ In Brazil, environmental offenses had been the only type of corporate criminal liability, with the Environmental Crimes Law enacted in $1998 .^{41}$ Criminal procedure rules, however, were not adapted to corporations, and criminal prosecutions for environmental crimes in Brazil remained rare. ${ }^{42}$

\section{Negotiated Corporate Settlements}

In the United States, corporate prosecutions have exploded in size. ${ }^{43}$ That is, more corporations are not being prosecuted by federal prosecutors, but the size of the penalties in the largest cases that have exponentially increased. Multi-billion dollar fines are now an annual occurrence. Many were quite high-profile prosecutions; well over half were public corporations, and many were Fortune 500 and Global 500 companies. $^{44}$

In the 1990 s, if corporations were prosecuted in the U.S., they were typically convicted and sentenced by a judge. Today, far more of the truly important corporate prosecutions do not result in a conviction but rather are resolved alternatives called deferred prosecution agreements. A deferred prosecution is filed with the court and consists in an agreement to toll the Speedy Trial Act deadlines and to keep the case inactive on the judge's docket until a time period for the defendant to comply is completed. Then the case is dismissed. Such agreements had been often used as an alternative to an indictment and conviction for first-time offenders or juveniles, but it was a new idea to use them in serious corporate cases. A non-prosecution agreement is a variant that is completely out of court; it is never filed with a judge. Rather, in it prosecutors agree that they will not file a case if the corporation complies with the terms of the agreement.

\footnotetext{
${ }^{39}$ OECD Convention on Combating Bribery of Foreign Public Officials in International Business Transactions (OECD Anti-Bribery Convention); United Nations Convention against Corruption (UNCAC).

${ }^{40} \mathrm{http}$ ///www.fcpablog.com/blog/2013/7/30/ukraine-enacts-sweeping-new-anti-corruption-legislation.html.

${ }^{41}$ Environmental Criminal Law, 9.605/1998.

${ }^{42} \mathrm{http}$ //fcpamericas.com/english/brazil/corporate-criminal-liability-united-states-brazil-comparative-analysis-2/.

${ }^{43}$ Brandon L. Garrett, Too Big to Jail: How Prosecutors Compromise with Corporations Ch.1, 294 (Harvard U. Press 2014) (describing an increase in average corporate fines over the past two decades, from less than $\$ 2,000,000$ in average fines per year before 2000, to over $\$ 15,000,000$ in average corporate fines by 2010).

${ }^{44} \mathrm{Id}$. at 62 (noting that thirty-one percent of corporations were either a Fortune or Global 500 firm the year they settled their prosecutions).
} 
The adoption of the U.S. Sentencing Guidelines Chapter designed specifically for organizations, in 1991, heralded an increase in corporate criminal fines. Those Guidelines included provisions to reduce fines for corporations with effective ethics and compliance programs, and they also based fines on the size of a company and the involvement of top-level officials. Thus, although the federal respondeat superior standard is broad, these Guidelines attempted to set out a more nuanced approach towards punishing corporations criminally. Under the federal Alternative Fines Act, a company can also be ordered to pay up to twice the "gross gain or loss" from the offense; the provision is not frequently used, however. ${ }^{45}$

In 1999, under then-Deputy Attorney General Eric Holder, the DOJ issued its first memo providing a set of guidelines to advise federal prosecutors on how to bring corporate prosecutions. ${ }^{46}$ At that time, however, prosecutors had only used a few deferred prosecutions with corporations. The idea was still novel. The deferred prosecution approach took off after a 2003 revision to the DOJ guidelines that added "Principles" for the prosecution of organizations in the U.S. Attorneys' Manual used by federal prosecutors. ${ }^{47}$ The DOJ has revised the guidelines several more times, including in Fall 2015 to emphasize the importance of investigating individual wrongdoing in corporate cases. The new guidelines now contain a section announcing the new "focus on individual wrongdoers" including from the earliest stages in a corporate criminal investigation. ${ }^{48}$ The revised principles also emphasize that cooperation credit will only be given to a company that identifies responsible individuals: "In order for a company to receive any consideration for cooperation under this section, the company must identify all individuals involved in or responsible for the misconduct at issue, regardless of their position, status or seniority." ${ }^{49}$ Prosecutors weigh as a separate factor self-reporting by firms in the form of a "timely and voluntary disclosure." ${ }^{50}$ The principles also add a section on coordinating parallel

\footnotetext{
${ }^{45} 8$ U.S.C. $\$ 2571(\mathrm{c})(3)$.

${ }^{46}$ Memorandum from Eric Holder, Deputy Attorney General, Department of Justice, to Component Heads and United States Attorneys, Bringing Criminal Charges Against Corporations (June 16, 1999).

${ }^{47}$ Memorandum from Deputy Att'y Gen. Larry D. Thompson, U.S. Dep't of Justice, to Heads of Dep't Components \& U.S. Attorneys, U.S. Dep't of Justice, Principles of Federal Prosecution of Business Organizations (Jan. 20, 2003) (called the "Thompson Memo" after the Deputy Attorney General who issued it).

${ }^{48}$ U.S.A.M, § 9-28.210.

${ }^{49}$ U.S.A.M, § 9-28.700.

${ }^{50}$ U.S.A.M, § 9-28.900.
} 
proceedings, to encourage cooperation between prosecutors and those pursuing civil, regulatory and administrative actions. ${ }^{51}$

However, the guidelines largely maintain a flexible approach, encouraging consideration of a broad set of factors when deciding whether to pursue an indictment or conviction, or alternatively, a deferred or non-prosecution agreement. Those factors include: (1) the nature and seriousness of the offense, (2) the pervasiveness of wrongdoing within the corporation, (3) the company's history of similar conduct, including civil and criminal actions; (4) the corporation's willingness to cooperate in investigation of its agents, (5) the corporate compliance program, (6) timely and voluntary disclosure of wrongdoing; (7) any remedial actions, such as firing wrongdoers and cooperating with government agencies; (8) the collateral consequences that a prosecution would cause, including to shareholders, (9) whether it would be sufficient to impose civil or regulatory remedies, and (10) the adequacy of prosecutions of individuals. ${ }^{52}$ Those factors are "illustrative" and not an exclusive or "exhaustive" list, and "no single factor will be dispositive." Thus, prosecutors retain substantial discretion to weigh these various considerations in any given case.

Despite that flexibility, common approaches can be observed when reading the terms of these agreements. Deferred prosecution agreements are commonly quite complex, as are the goals of these corporate prosecution agreements. The agreements can include criminal fines, as well as other penalties such as restitution to victims, civil forfeiture, payments to regulators, and community service payments. They can specify compliance terms, including creation of new positions to supervise compliance, changes to governance, new auditing systems, and retention of independent monitors to supervise compliance. The DOJ's guidelines note prosecutors should try to assess whether the compliance program is just a "paper program" and should consider "whether the corporation has provided for a staff sufficient to audit, document, analyze, and utilize the results of the corporation's compliance efforts." 53 The DOJ has also made new efforts to conduct detailed review of such compliance provisions. These agreements typically last from two to three years.

I have examined the terms of these U.S. deferred and non-prosecution agreements with corporations in some details. About one quarter require the retention of monitors to supervise

\footnotetext{
${ }^{51}$ U.S.A.M, $\S 1-12.000$.

${ }^{52}$ Id. $\S \S 9-28.000-9-28.100,9-28.300$.

${ }^{53}$ U.S.A.M. 9-28.800.
} 
compliance, but most do not. The fines are often not all that they could be. I collected a set of federal deferred and non-prosecution agreements beginning in $2001 .^{54}$ I was surprised to learn that in almost half of the deferred and non-prosecution agreements with companies entered from 2001-2012, no criminal fine was imposed..$^{55}$ I also found that for public companies prosecuted from 2001-2012, total payments made to prosecutors averaged just 0.09 percent of market capitalization. ${ }^{56}$ From 2001-2014, prosecutors entered 306 deferred and non-prosecution agreements with companies. Among those, only 34 percent or 103 companies had officers or employees prosecuted, with 408 total individuals prosecuted. Few of those individuals were higher-up officers or executives.

U.S. prosecutors have also targeted financial institutions far more than ever before. In recent cases, they have not used deferred prosecution agreements but rather secured guilty pleas from banks. ${ }^{57}$ The principles do say that "prosecutors should generally seek a plea to an appropriate offense," and also that "generally" this should be a plea to the "most serious, readily provable offense charged. ${ }^{, 58}$ While the guidelines regarding organizational prosecutions in the U.S. do not state with any specificity when a conviction is appropriate versus a deferred prosecution agreement, prosecutors do appear more willing to seek convictions, including in high profile cases, than in the past decade, when many of the most significant corporate prosecutions were resolved out of court.

\section{Canada}

In Canada, corporations may plead guilty, under a plea bargaining system in which the judge may accept or reject the plea and the judge ultimately imposes the sentence. The plea agreements are not made public, but the accompanying statements of facts are public. ${ }^{59}$ In addition to any penalty, a fifteen percent surcharge is added towards provincial victim restitution

\footnotetext{
${ }^{54}$ I have maintained for some time the most complete data available on such federal deferred and non-prosecution agreements with corporations. See Brandon L. Garrett \& Jon Ashley, Federal Organizational Prosecution Agreements, University of Virginia School of Law, (last updated July 31, 2015).

${ }^{55}$ Garrett, Too Big to Jail, supra note 6, at 69.

${ }^{56}$ Id. at 150 (noting that few deferred or non-prosecution agreements from 2001-2012 included a guidelines calculation, only 30 of them, and only three of those noted fines at the top of the applicable range).

${ }^{57}$ Brandon L. Garrett, The Rise of Bank Prosecutions, 126 Yale L.J. Forum 33 (2016).

${ }^{58}$ U.S.A.M, § 9-28.1500.

${ }^{59}$ OECD, Phase 3 Report on Implementing the OECD Anti-Bribery Convention in the Canada (2011), 20, 22, at http://www.oecd.org/daf/anti-bribery/anti-briberyconvention/Canadaphase3reportEN .pdf.
} 
funds. ${ }^{60}$ The approach does not permit the type of informal corporate settlements that are now common in the U.S., but there has been some discussion of the possibility of introducing deferred prosecution agreements in Canada.

\section{United Kingdom}

In the United Kingdom, corporations have long been criminally liable. Corporations have often settled criminal cases through guilty pleas. In such cases, the corporation admits guilt and receives a conviction. In addition, corporations may enter a Civil Recovery Order, in which a payment is made but there is no civil judgment. ${ }^{61}$ The United Kingdom adopted deferred prosecution agreements with corporations by statute in the Crime and Courts Act of $2013 .{ }^{62}$ One event prompting the legislation was the concern raised by the judge in the Innospec case, involving foreign bribery charges resolved in a 2010 settlement between the Serious Fraud Office, as well as prosecutors in the U.S. The judge called argued that in any criminal settlement process, "it is for the court to decide on the sentence and to explain that to the public." ${ }^{\prime 33}$ The high court judge ruled prosecutors had unconstitutionally reached a sentencing arrangement with the company and that "no such arrangements should be made again."

The 2013 legislation permits such corporate settlements, but only with judicial oversight and approval. A detailed code of practice for prosecutors was published by the Crown Prosecution Service and Serious Fraud Office accompanying the legislation, and emphasizing the importance of the public interest in whether to offer a DPA. ${ }^{65}$ The prosecutor must obtain a declaration from a judge that the DPA is "likely to be in the interests of justice" and that the terms are "fair, reasonable, and proportionate." ${ }^{.66}$ Once the agreement is negotiated, the terms are presented to the Crown Court for approval, and the judge can review the substance of the agreement and decide whether the agreement is "fair, reasonable, and proportionate." ${ }^{67}$ In

\footnotetext{
${ }^{60}$ See Department of Justice (Canada), "Provisions of Interest to Victims of Crime," http://www.justice .gc .ca/eng/cj-jp/victims-victimes/code.html.

${ }^{61}$ World Bank/STAR, supra note 1, at 26-27.

${ }^{62}$ Crime and Courts Act of 2013, at http://www.legislation.gov.uk/ukpga/2013/22/schedule/17/enacted.

${ }^{63} \mathrm{http}: / /$ www.banksr.co.uk/images/Other\%20Documents/Crown\%20Court\%20decisions/R\%20v\%20Innospec.pdf.

${ }^{64} \mathrm{Id}$.

${ }^{65}$ U.K. Crown Prosecution Service and Serious Fraud Office "Deferred Prosecution Agreements Code of Practice" (2014), at https://www.cps.gov.uk/publications/directors_guidance/dpa_cop.pdf.

${ }^{66}$ Section 45 of and Schedule 17(7) to the U.K. Crime and Courts Act 2013.

${ }^{67} I d$. at Schedule 17(8)(1).
} 
addition, any failure to comply with a DPA has consequences set out and a judge will adjudicate any possible breach. The first deferred prosecution agreement in the U.K., with Standard Bank, was approved by the judge, noting, in contrast to the situation in Innospec, that the court was permitted to make a "detailed analysis" of the circumstances of the offense and the financial penalty imposed and that "there is no question of the parties having reached a private compromise without appropriate independent judicial consideration of the public interest.",68

\section{France}

In France, while corporate criminal liability existed, a statutory scheme that permits judicially-approved settlements with corporations in foreign bribery cases was recently enacted in Fall 2016. This Sapin II legislation calls for regulation of corporate compliance programs, the creation of a new French anti-bribery agency to issue such regulations, as well as the adoption of specific provisions regarding judicial review and approval of deferred prosecution agreements in criminal cases. ${ }^{69}$ The French lawmakers explicitly rejected the proposal to adopt a U.S.-style model in which deferred prosecution agreements with corporations could be entered largely out of court. Instead, the Sapin II legislation adopts a model more along the lines of the U.K. approach in which judicial review is required, but also with more involvement and regulation by an administrative agency overseeing anti-corruption efforts.

\section{Additional Out-of-Court Settlement Approaches}

Other countries have long used more informal settlement mechanisms in corporate crime cases. The Netherlands permits out of court settlements with corporations under article 74 of the Dutch Criminal Code and a Directive on Large and Special Transactions. ${ }^{70}$ Several foreign bribery cases have been resolved through such settlements. For example, in 2016, Openbaar Ministerie entered such a settlement with Russian telecom company Vimpelcom, which

\footnotetext{
${ }^{68}$ Serious Fraud Office v Standard Bank Plc: Deferred Prosecution Agreement (Case No: U20150854), English High Court, Queen's Bench Division (Leveson P), 30 November 2015, at https://www.judiciary.gov.uk/wpcontent/uploads/2015/11/sfo-v-standard-bank_Final_1.pdf.

${ }^{69} \mathrm{https}: / / \mathrm{www} . w h i t e c a s e . c o m /$ publications/alert/update-sapin-ii-law

${ }^{70}$ Debevoise and Plimpton, Small Country, Big Punch: the Netherlands Anti-Bribery Prosecution of SBM Offshore, December 2014, http://www .lexology.com/library/detail.aspx?g=1 ef21f00-f4af-4e39-a0f6-2b309dd9bb6f.
} 
simultaneously settled with the U.S. Department of Justice, and with almost $\$ 400$ million paid to Dutch and U.S. authorities. ${ }^{71}$ In Norway, corporate prosecutions are also often settled out of court. In Norway, the mechanism is a penalty notice in which the prosecutor sets out the fine to be imposed. ${ }^{72}$ Økokrim, the Norwegian authority that handles economic and environmental crimes, frequently uses penalty notices in corporate cases. ${ }^{73}$ Økokrim explained to the OECD in 2011 that "economic crime trials are usually very lengthy and a much bigger burden on law enforcement resources .... furthermore, representatives of companies sometimes also prefer a swifter conclusion to a case to minimise the reputational risks to their corporation." ${ }^{, 74}$

In Italy, corporations may settle criminal matters under the patteggiamento system, which resembles a plea bargain, and is overseen by judges. ${ }^{75}$ If a company enters a patteggiamento, the entity may obtain a one-third reduction in the penalty, avoid making an admission of guilt, avoid debarment or other regulatory sanctions, and benefit from a possible "extinction" of the sentence after five years. The OECD has criticized the lack of information made public in cases in which companies settle charges using a patteggiamento. ${ }^{76}$

Other countries use informal mechanisms to resolve corporate charges. Switzerland uses a summary punishment order, typically used for misdemeanor offenses, and a mechanism called "Reparation" after which charges are dropped if the defendant provides compensation. ${ }^{77}$ In foreign bribery cases, including regarding Alstom and a subsidiary of Siemens, Reparation was used to settle cases. ${ }^{78}$ Greece has settled foreign bribery cases against corporations using Parliamentary decree. ${ }^{79}$ In Brazil, the Federal Public Ministry has entered leniency agreements

\footnotetext{
${ }^{71}$ https://www.om.nl/algemeen/english/@93227/vimpelcom-pays-close/.

${ }^{72} \mathrm{http}: / /$ thebriberyact.com/2014/12/12/the-corruption-enforcement-view-from-norway-by-frode-elgesem/.

${ }^{73}$ OECD Working Group on Bribery, Phase 3 Report on implementing the OECD Anti-Bribery Convention in Norway, June 2011, http://www.oecd.org/daf/anti-bribery/anti-briberyconvention/Norwayphase3reportEN.pdf.

${ }^{74}$ Ibid. Para 64

${ }^{75}$ OECD Working Group on Bribery, Phase 3 Report on implementing the OECD Anti-Bribery Convention in Italy, December 2011, http://www.oecd.org/daf/anti-bribery/anti-briberyconvention/Italyphase3reportEN.pdf.

${ }^{76}$ OECD Working Group on Bribery, Italy: Follow-up to the Phase 3 Report and Recommendations, May 2014, http://www.oecd.org/daf/anti-bribery/ItalyP3WrittenFollowUpReportEN.pdf

${ }^{77}$ Sections 352, 358 of the Swiss Code of Criminal Procedure (SCCP).

${ }^{78}$ See Case EAII.04.0325-LEN, Alstom Network Schweiz AG, summary punishment order under Article 352 of the Swiss Code of Criminal Procedure (SCCP) (22 November 2011); see also OECD Working Group on Bribery, "Phase 3 report on implementing the Anti-Bribery Convention in Switzerland," December 2011: http://www.oecd.org/daf/anti-bribery/anti-briberyconvention/Switzerlandphase3reportEN.pdf

${ }^{79}$ World Bank/Star, supra note 1, at 131-133.
} 
with corporations, most prominently, with Odebrecht regarding the national Operation Car Wash scandal; questions remain whether other government agencies will honor the settlement. ${ }^{80}$

\section{Concerns with Corporate Prosecution Settlement Approaches}

While the settlement-oriented approach towards corporate prosecutors has provided prosecutors with a great deal of flexibility, concerns have been raised with that approach in the U.S. and internationally. As discussed, countries such as the U.K. and France have adopted settlement regimes that involve more judicial supervision to alleviate concerns with such settlements, while preserving some of the flexibility that they provide. A series of functional considerations should be considered when deciding whether and how to pursue corporate prosecutions.

Transparency has been one concern raised regarding corporate settlements. Full trial or full criminal process can produce a public record concerning the crimes committed, full notification to victims, and a public trial or at least a public sentencing. Corporate defendants, of course, seek to avoid negative publicity in reaching a settlement with the authorities. One benefit corporate defendants may receive is the ability to not fully admit guilt (in the U.S., that is done in civil cases, but an admission of guilt is routine in criminal settlements). Some settlements do report the amounts of fines paid and some description of the facts, but often not based on a complete record or a detailed statement of facts. A separate concern has been with the amount of the fines themselves and how they are calculated. The DOJ has stated that punishment and deterrence can be accomplished by "substantial fines." ${ }^{\prime 1}$ What amount is appropriate, though, may be difficult to assess. The harm to victims may be difficult to calculate, and the profit to a corporate may be hard to measure of a financial scheme was not fully carried out. Legislation was proposed in the U.S. Senate, although not enacted, to require greater transparency in corporate fines. ${ }^{82}$ Organizational sentencing guidelines in the U.S. set out detailed criteria for

\footnotetext{
${ }^{80}$ Maira Magro, Odebrecht Fears “Government Disloyalty” In Leniency Agreements, Valor, March 13, 2017.

${ }^{81}$ U.S.A.M, § 9-28.1500.

${ }^{82}$ Danielle Douglas, Senate Bill Targets Corporations That Deduct Settlement Payouts, Wash. Post. Nov. 6, 2013 (describing proposed Government Settlement Transparency and Reform Act.
} 
corporate fines, but they have been criticized and they are often not used in cases that settle through deferred or non-prosecution agreements. ${ }^{83}$

An additional concern has been with the structural or compliance terms of agreements. Without judicial review, prosecutors may be less able than judges or regulators to independently assess whether corporations are complying fully with the non-financial terms of the agreements. The DOJ has retained a compliance counsel to focus on reviewing and improving the compliance terms of corporate agreements. ${ }^{84}$ Recently, the DOJ has issued guidance on the subject of corporate compliance, which is another improvement. In the past, many agreements had stated that a company should adopt best practices or a compliance program, but without specifying how it should do so or whether or how compliance efforts should be assessed. ${ }^{85}$

A separate concern has been that when prosecutors settle with corporations, while they may impose fines and compliance reforms, they may fail to prosecutor or deter executives other individual culprits. I have found, for example, that in only about a third of deferred and nonprosecution agreements, are any individuals prosecuted, and very few of those that are prosecuted are higher-up officers or executives. ${ }^{86}$ Securing the cooperation of the corporation in investigations of individuals should be a central goal of corporate criminal liability, but in the past, that goal was not emphasized in the U.S. The more recent changes to the prosecution guidelines, in the Fall 2015 Yates Memo, may have placed more focus on individual accountability, but it is too early to tell whether that additional guidance will be effective.

Judicial supervision may be limited for settlements. A separate concern has been that the public interest may be neglected without independent judicial review, or that prosecutorial discretion may be too great. The General Accountability Office criticized the DOJ in the U.S. for lack of criteria for deciding whether a company receives a deferred or non-prosecution agreements. ${ }^{87}$ In 2013, federal judge Richard J. Leon rejected a deferred prosecution agreement with a company for foreign bribery, "looking at the DPA in its totality" and noting that not only

\footnotetext{
${ }^{83}$ See, e.g., Jennifer Arlen, The Failure of the Organizational Sentencing Guidelines, 66 Miami L. Rev. 231 (2012). For an overview, see Garrett, Too Big to Jail, supra at Ch. 6.

${ }^{84}$ Press Release, Department of Justice, New Compliance Counsel Expert Retained by the DOJ Fraud Section, November 3, 2015, at http://www.justice.gov/criminal-fraud/file/790236/download.

${ }^{85}$ Garrett, Too Big to Jail, supra note $\mathrm{xxx}$ at Ch.2.

${ }^{86}$ Jed S. Rakoff, The Financial Crisis: Why Have No High-Level Executives Been Prosecuted?, The N. Y. Rev. of Books, Jan. 9 2014; Brandon L. Garrett, The Corporate Criminal as Scapegoat, 101 Virginia L. Rev. 1789 (2015).

${ }^{87}$ Government Accountability Office, Preliminary Observations on the DOJ's Use and Oversight of Deferred Prosecution and Non-Prosecution Agreements, June 25, 2009, 41.
} 
were "no individuals . . being prosecuted for their conduct at issue here" but also "a number of the employees who were directly involved in the transactions are being allowed to remain with the company." ${ }^{88}$ However, the D.C. Circuit Court of Appeals rejected that ruling and held that the judge exceeded his discretion. ${ }^{89}$ In another case, Judge Emmett Sullivan suggested that certain factors (could provide "useful guideposts" when evaluating whether a deferred prosecution agreement with a company is truly "designed to secure a defendant's reformation" or whether the terms are "so vague and minimal as to render them a sham." ${ }^{90}$ In contrast, in countries in which judges may review and decide whether charges are appropriately brought against a defendant, and judges decide upon the sentence ultimately imposed, prosecutors cannot exercise nearly as much discretion when negotiating with corporations. ${ }^{91}$

Countries have very different systems of criminal procedure, and those procedural rules may impact the desirability of settlement regimes and of corporate criminal liability itself. For example, in the U.S., corporations may decide to waive attorney-client privilege on behalf of employees, giving them a great deal of leverage in negotiations and also making the cooperation of the corporation extremely important in order to access evidence during investigations. ${ }^{92}$ In countries in which evidentiary privileges are narrower, corporate investigations might be more feasible without that corporate cooperation. In contrast, in countries in which employees are not typically at-will and labor protections are stronger, it may be far more difficult for a corporation to encourage or pressure employees or officers to cooperate with law enforcement. Civil law alternatives may be important as well. If a country has adequate resources for civil corporate investigations and sufficient penalties are available, civil enforcement may effectively substitute for criminal enforcement against corporations.

Prosecutorial power is extremely broad in the U.S. Prosecutors have broad discretion to charge and to negotiate sentences through plea bargains and other types of agreements with defendants. That broad authority makes relatively more informal negotiated settlement regimes far more practicable in the U.S. than in countries in which judicial review would be presumed and out-of-court negotiations frowned upon or deemed unauthorized by law or unconstitutional.

\footnotetext{
${ }^{88}$ USA v. Fokker Services B.V., Docket No. 1:14-cr-00121 (D.D.C. Jun 04, 2014).

${ }^{89}$ United States v. Fokker Servs., B.V., 818 F.3d 733, 742 (D.C. Cir. 2016).

${ }^{90}$ Saena Tech Memorandum and Order at 45.

91 Jenia Iontcheva Turner, Judicial Participation in Plea Negotiations: A Comparative View, 54 Am. J. Comp. L. 199, 215 (2006)

${ }^{92}$ See Upjohn Co. v. United States, 449 U.S. 383 (1981).
} 
Prosecutors in the U.S also have strong resources, the ability to bring complex cases to trial, and broad jurisdiction due to the role of trade with the U.S., the role that the U.S. dollar plays in international finance, and the U.S.-based stock exchanges, over a wide range of international corporations. Multinational criminal cases can be readily brought in U.S. courts. The same is not true of the courts in many countries. That gives U.S. prosecutors an especially prominent role in corporate regulation generally, and in corporate criminal liability in particular.

Settlements also have some important advantages. They can permit more efficient use of law enforcement resources, particularly in highly complex cases. Settlements can avoid firms suffering collateral consequences of a conviction such as debarment or suspension from government contracting or participation in a regulated industry. In the United States as well as in the European Union, for example, bribery convictions can result in debarment. ${ }^{93}$ Fines may be reduced to encourage cooperation in investigations of other companies and individuals. Fines may also be reduced to reflect parallel settlements in other countries. Negative publicity may be reduced for the company. What balance is appropriate between the advantages of more informal and flexible settlements and the advantages of more formal and rule-governed judicial resolutions, is a difficult moral and policy question. It is far from clear that any country has the right balance.

\section{International Cooperation}

International organizations have played a role in corporate prosecutions and in promoting corporate accountability norms. For example, the United Nations and the World Bank have played a rule in foreign bribery cases. ${ }^{94}$ The OECD has played an important role in Antitrust and foreign bribery work. The OECD Anti-Bribery Convention has established binding legal standards on member nations, and as the first such international law regime, it has had a great deal of influence. In addition, the OECD has promoted best practices, made recommendations, and evaluated member countries in reviews and reports. The OECD has provided advice to countries to combat tax crimes.

\footnotetext{
93 See Article 45 of the EU Procurement Contracts Directive http://eur-lex.europa.eu/LexUriServ /LexUriServ.do?uri=CELEX:32004L0018:en:NOT; Regulation 23 of the Public Contracts Regulations (2006) and Regulation 26 of the Utilities Contracts Regulations (2006) (U.K. implementation of the directive).

${ }^{94}$ WorldBank/STAR, supra note 1 at 44.
} 
Parallel and collaborative prosecutions are also increasingly common. For example, in the Siemens case, the DOJ and the Securities and Exchange Commission (SEC) in the U.S. collaborated with the Munich Public Prosecutor's Office and German authorities, including based on mutual legal assistance provisions of the OECD Convention. The plea bargain by Siemens included $\$ 800$ million in fines paid to the DOJ and SEC and $\$ 800$ million in fines paid to the Munich Public Prosecutor's Office. ${ }^{95}$ The agreement also included two corporate monitors, one Independent U.S. Counsel, and a German corporate monitor, Dr. Theo Waigel, a former German Minister of Finance. The employees prosecuted in the case were convicted by Munich prosecutors; individuals were indicted in the U.S. but none so far successfully extradited. ${ }^{96}$ The Fraud Section at DOJ has emphasized the role that international cooperation plays in foreign bribery cases generally, which are international crimes. The Antitrust Division similarly has emphasized joint investigations and mutual assistance agreements in its cartel enforcement, and it has worked with the International Competition Network and the OECD to promote cooperation. $^{97}$

\section{Conclusion}

Corporate criminal enforcement has increased in frequency and in the size of monetary sanctions over the past decade. More countries have successfully prosecuted corporations, particularly in areas like antitrust and foreign bribery. Most of the prosecutions and settlements have been brought in countries that are major financial centers, with the bulk being brought in the United States, but also in the U.K., France, Germany, and increasingly in certain developing countries. The tools to resolve these corporate prosecutions are increasingly varied, using civil, criminal, and hybrid mechanisms. Parallel enforcement is far more common, with cooperation between enforcement agencies. As countries consider whether to adopt new tools to combat corporate crime, they should pay attention to both the successes of new approaches and to concerns raised regarding whether they serve the public interest. In the past, the common

\footnotetext{
${ }^{95}$ Press Release, U.S. Dep't of Justice, Siemens AG and Three Subsidiaries Plead Guilty to Foreign Corrupt Practices Act Violations and Agree to Pay $\$ 450$ Million in Combined Criminal Fines (Dec. 15, 2008), http://www.usdoj.gov/opa/pr/2008/December/08-crm-1105.html.

96 Ex-Siemens Execs Found Guilty in Bribery Case, Reuters, Apr. 20, 2010, at Factiva, Doc. No. LBA0000020100420e64k00114.

${ }^{97}$ Gary R. Spratling \& D. Jarrett Arp, The International Leniency Revolution 8-9 (2003), available at http:// www.gibsondunn.com/publications/pages/TheInternationalLeniencyRevolution.aspx.
} 
approach was to use corporate criminal enforcement sparingly and in limited form. As corporate crimes have grown in scale and in social harm, enhancing corporate liability for such crimes is a sensible idea. Tailoring enforcement to ensure both individual and corporate-level accountability, to ensure transparency and adequate incentives for cooperation and remediation, and to deter and prevent future crimes: that is the challenge going forward. The new international dialogue concerning corporate criminal liability will hopefully contribute to new experimentation and improved approaches towards corporate crime.

Bibliography

Sara Sun Beale and Adam G. Safwat, What Developments in Western Europe Tell Us about American Critiques of Corporate Criminal Liability, 8 Buffalo Crim. L. Rev. 110 (2004)

Edward B. Diskant, Comparative Criminal Liability: Exploring the Uniquely American Doctrine Through Comparative Criminal Procedure, 118 Yale L. J. 126, 134-35 (2008)

Brandon L. Garrett, Too Big to Jail: How Prosecutors Compromise with Corporations Ch.1, 294 (Harvard U. Press 2014)

Brandon L. Garrett, Globalized Corporate Prosecutions, 97 Virginia Law Review 1775 (2011)

Mark Pieth and Radha Ivory, Emergence and Convergence: Corporate Criminal Liability Principles in Overview, in Corporate Criminal Liability (Peith and Ivory, eds., Springer 2011)

OECD, The Liability of Legal Persons for Foreign Bribery: A Stocktaking Report (2016), 